\title{
Evaluation of Secondary School 10th Grade Chemistry Instructional Curriculum
}

\section{Anıl ÖZTEKİN ${ }^{1, *}$ \& Kemal Oğuz ER ${ }^{2}$}

\author{
${ }^{1}$ Balıkesir Anatolian Religious High School, Balıkesir, TURKEY; ${ }^{2}$ Balıkesir \\ University, Balıkesir, TURKEY
}

Received: 06.09.2013

Accepted: 28.02 .2014

\begin{abstract}
In this study it was aimed to evaluate 10th grade Chemistry Curriculum in terms of general aims, educational attainments, activities and evaluation according to the opinions of teachers who are responsible for implementation of curriculum and to introduce some suggestions for development of the curriculum. Mixed method was used in the study. The results of this study showed that (1) the general aims are complementary and supportive for each other but not in appropriate level for students, (2) the most problematic unit in the curriculum is "The structure of an Atom" because students had problems to gain the educational attainments about this unit, (3) the activities are included in curriculum in details, but the curriculum is not qualified for implementation of different activities in classroom simultaneously, (4) the evaluation is consistent with the content and the educational attainments but traditional and performance-based assessment tools are not appropriate for the curriculum.
\end{abstract}

Key words: program evaluation, 10th grade chemistry curriculum, chemistry teaching.

DOI No: 10.12973/nefmed.2014.8.1.a6

\begin{abstract}
Summary
Introduction

Advancements in science are the basis of scientific and technological developments in addition to providing great contributions to economic development of countries. It leads to an increase in importance of science and science education constantly (Ayas, Çepni \& Akdeniz,1993).
\end{abstract}

\footnotetext{
* Corresponding author: Anıl ÖZTEKİN, Dr., Balıkesir Anatolian Religious High School, Balıkesir, TURKEY E-mail: anil_oztekin@yahoo.com
}

Note: This study is a part of Anıl ÖZTEKIN PhD thesis. 
Chemistry, as a part of science, examines all substances in nature and interactions between them by means of its own concepts, symbols and principles. With teaching of chemistry to individuals it is tried to gain scientific thinking skills in the context of positive and negative effects of chemistry on environment and human life besides the basic structure of a substance, interactions between substances, and matter-energy relationships (URL-1). Ünal, Coştu \& Karataş (2004) who drew attention to the importance of curriculums in improving the quality of science education stated that existing curricula should be reevaluated and the newly developed ones should be in the light of the data obtained from these evaluations.

When the development of chemistry curricula in Turkey was examined, it was seen that many changes in the curricula were made by taking current conditions into consideration. However, there have been no evolutionary studies manifesting the effectiveness of the curriculum within the framework of scientific principles and curriculum evaluation approaches after implementing the changed curriculum. In this context, evaluation of the 10th grade Chemistry Curriculum, which was changed in 2008 and implemented for a period of four years from 2009-2010 academic years, according to the views of the teachers is the main purpose of this study.

\section{Methodology}

A mixed method including qualitative and quantitative research methods is used in the study. Participants consist of 156 chemistry teachers working in 84 secondary schools in the province of Balıkesir and its townships in 2011. Qualitative and quantitative data collection methods are used together to obtain data about research problems. Quantitative data collected by a survey is analyzed by using percentage and frequency. Qualitative data, collected by an interview form, is analyzed with content analysis method.

\section{Discussion and Conclusion}

The results of this study showed that (1) the general aims are complementary and supportive for each other but not in appropriate level for students, (2) the most problematic unit in the curriculum is "The structure of an Atom" because students had problems to gain the educational attainments about this unit, (3) the activities are included in curriculum in details, but the curriculum is not qualified for implementation of different activities in classroom simultaneously, (4) the evaluation is consistent with the content and the educational attainments but traditional and performance-based assessment tools are not 
appropriate for the curriculum. Besides, teachers have negative opinions on grounds that they were not adequately informed about the program, they did not find the program applicable and prerequisites were not considered in the order of the subjects. In addition, teachers state that educational attainments of the curriculum are higher than students' levels of development and readiness; course duration, examples of methods-techniques, and measuring and evaluation tools are insufficient; activities are not qualified enough to attract students' attention. 


\title{
Ortaöğretim 10.Sınıf Kimya Dersi Öğretim Programının Değerlendirilmesi
}

\author{
Anıl ÖZTEKİN ${ }^{1,+}$ ve Kemal Oğuz ER ${ }^{2}$ \\ ${ }^{1}$ Balıkesir Anadolu İmam Hatip Lisesi, Balıkesir, TÜRKİYE; ${ }^{2}$ Balıkesir \\ Üniversitesi, Balıkesir, TÜRKİYE
}

Makale Gönderme Tarihi: 06.09.2013

Makale Kabul Tarihi: 28.02.2014

Özet - Bu çalışmada, Ortaöğretim 10. Sınıf Kimya Dersi Öğretim Programını, genel amaçlar, kazanımlar, etkinlikler ve değerlendirme boyutları açısından, programın uygulayıcıları olan öğretmenlerin görüşlerine göre değerlendirmek ve programın geliştirilmesine ilişkin öneriler ortaya koymak amaçlanmıştır. Çalışmada karma yöntem kullanılmıştır. Araştırmada, (1) programda yer alan genel amaçların birbirini tamamlayıcı ve destekler nitelikte olduğu ancak öğrencilere kazandırılabilecek düzeyde olmadığı; (2) en fazla "Atomun Yapısı" ünitesindeki kimya içerik kazanımlarının kazanılmasında sorun yaşandığı; (3) etkinliklerin programda ayrıntılı olarak yer aldığı ancak programın, sınıf ortamında farklı etkinliklerin aynı anda uygulanmasına uygun nitelikte olmadığı; (4) değerlendirmenin içerik ve kazanımla tutarlı olduğu ancak geleneksel ve performansa dayalı ölçme araçlarının programa uygun nitelikte olmadığı sonuçlarına ulaşılmıştır.

Anahtar kelimeler: program değerlendirme, ortaöğretim 10. sınıf kimya dersi öğretim programı, kimya öğretimi.

\section{DOI No: 10.12973/nefmed.2014.8.1.a6}

\section{Giriş}

Canlı ve cansız varlıkları ve bunlar arasındaki ilişkileri sebep ve sonuçlarıyla tartışarak ortaya koymaya çalışan bir disiplinler topluluğu olan fen bilimlerinde keşfedilen bilgiler, yaşamı kolaylaştıran teknolojiler şeklinde topluma yansıyabilmektedir. $\mathrm{Bu}$ yönüyle teknolojinin esas kaynağı olarak görülen fen bilimleri, ülkelerin gelişmesinde ve ekonomik kalkınmasında önemli bir yere sahiptir. Bu nedenle ülkeler, bilim ve teknolojinin hızla ilerlediği dünyamızda bilimsel ve teknolojik gelişmelerden geri kalmamak, ilerlemenin sürekliliğini sağlamak ve üretken bireyler yetiştirmek amacıyla fen bilimleri eğitimine özel bir önem vermektedirler (Ayas, 1995; Ünal, Coştu, Karataş, 2004).

\footnotetext{
† İletişim: Anıl ÖZTEKIN, Dr., Balıkesir Anadolu İmam Hatip Lisesi, Balıkesir, TÜRKIYE

E-mail: anil_oztekin@yahoo.com

Not: Bu çalışma Anıl ÖZTEKİN’ in doktora tezinin bir bölümüdür.
} 
Fen bilimlerinin önemli bir dalı olan kimya, deneyler yardımıyla maddenin yapı ve davranışlarını belirleyip doğadaki olayların gözlemlenmesini sağlayan, deney yoluyla bulunan sonuçların doğruluğunu kontrol edip formül ve prensipler belirleyen bir bilim dalıdır (Hawkes, 2001; Ergin, Akgün, Küçüközer \& Yakal, 2001). Kimyada kimyasal değişmeler, mol, molekül ve tanecik ilişkileri ve bunlara dayalı hesaplamalar ile soyut kavramlar oldukça fazla yer almaktadır (Schmidth, 1990; Schmidth, 1994).

Yaşamın kimyasal temelini anlama, olumlu etkileşimlerden yararlanma ve olumsuz etkileşimlerle başa çıkmada işlevsel bir kimya eğitimi alınması gereklidir (Novak \& Gowin, 1984). Kimya konularının çok teorik olması, kuram ve prensiplerin fazla sayıda bulunması, atom ve moleküllerin öğrenciler için somutlaştırılmaması ve öğrenilen bilgilerin gerçek yaşamla doğrudan bağlantısının kurulamaması kimya eğitiminin en önemli problemlerindendir (Herron \& Nurrenbern, 1999). Bu nedenlerle öğrencilerin bilimsel ve üst düzey düşünme becerilerini kazanmalarında önemli bir rolü olan kimyanın öğrencilere iyi hazırlanmış nitelikli programlarla öğretilmesi gerekmektedir. Nitelikli programlara ulaşmak için de mevcut programların program değerlendirme ve geliştirme ilkeleri doğrultusunda sürekli olarak değerlendirilmeleri ve geliştirilmeleri gerekmektedir.

Ünal, Coştu \& Karataş (2004) çalışmalarında, 1923-1997 yılları arasında ülkemizde geliştirilen fen programlarını; planlama, uygulama ve değerlendirme aşamalarını dikkate alarak incelemişlerdir. Araştırmanın sonucunda; tarihsel süreç içerisinde ülkemizde geliştirilen programlara genel olarak bakıldığında, programların planlama aşamalarında ayrıntılı ihtiyaç analizlerinin yeterince yapılmadığ 1 , programların uygulama sürecinde gerekli olan koşulların tüm okullara sağlanamadığı ve programların uygulanması sonrası etkili değerlendirmelerin yapılamadığı ortaya konmuştur.

2008 yılında, 2009-2010 eğitim öğretim yılından itibaren uygulanmakta olan Ortaöğretim 10. Sınıf Kimya Programı yürürlüğe girmiş ve Talim ve Terbiye Kurulu Başkanlığı'nın 12.09.2011 tarih ve 132 sayılı kararı ile programda değişiklik yapılmıştır. Programdaki ikinci değişiklik, Talim ve Terbiye Kurulu Başkanlığı’nın 29.03.2012 tarih ve 15 sayılı kararı ile gerçekleştirilmiştir. Üçüncü değişiklik ise Talim ve Terbiye Kurulu Başkanlığı'nın 01.02.2013 tarih ve 11 sayılı kararı ile 2013-2014 öğretim yılından itibaren 9. sınıflardan başlamak ve kademeli olarak uygulanmak üzere gerçekleştirilmiştir.

Yukarıdaki açıklamalar, program değerlendirme yaklaşım ve modelleri çerçevesinde bir değerlendirme yapılmadan, programlarda sürekli değişiklik olduğunu göstermektedir. $\mathrm{Bu}$ bağlamda, 2008 yılında değiştirilen ve 2009-2010 eğitim-öğretim yılından itibaren 
uygulanmakta olan 10.Sınıf Kimya Dersi Öğretim Programının, öğretmen görüşlerine göre değerlendirilmesi bu çalışmanın ana amacını oluşturmaktadır.

$\mathrm{Bu}$ amaç doğrultusunda aşağıda yer alan alt problemlere cevap aranmıştır.

1. Öğretmenlerin Ortaöğretim 10.Sınıf Kimya Dersi Öğretim Programının genel amaçlarına ilişkin görüşleri nelerdir?

2. Öğretmenlerin Ortaöğretim 10.Sınıf Kimya Dersi Öğretim Programının kazanımlarına ilişkin görüşleri nelerdir?

3. Öğretmenlerin Ortaöğretim 10.Sınıf Kimya Dersi Öğretim Programının etkinliklerine ilişkin görüşleri nelerdir?

4. Öğretmenlerin Ortaöğretim 10.Sınıf Kimya Dersi Öğretim Programının değerlendirme boyutuna ilişskin görüşleri nelerdir?

5. Öğretmenlerin Ortaöğretim 10.Sınıf Kimya Dersi Öğretim Programına ilişkin genel görüşleri nelerdir?

6. Çalışmada değerlendirilen 03.06.2008 tarihli program ile 01.02.2013 tarihinde değişen yeni kimya dersi öğretim programı arasındaki farklılıklar nelerdir?

\section{Araştırmanın Önemi}

Talim ve Terbiye Kurulu Başkanlığı'nın 03.06.2008 tarih ve 136 sayılı kararı ile 20092010 eğitim öğretim yılından itibaren uygulanmakta olan 10.Sınıf Kimya Dersi Öğretim Programını genel amaç, kazanım, etkinlik ve değerlendirme öğelerini dikkate alarak ve uygulayıcıları olan öğretmenlerin görüşlerine başvurarak değerlendirmeyi amaçlayan bu çalışma, programın güçlü ve zayıf yönlerini ortaya koyma varsa eksikliklerini belirleme, programın etkililiği hakkında karar verme ve bu çerçevede "Programın Öğelerine Dönük Değerlendirme" ile "Katılımcı Yönelimli" değerlendirme yaklaşımları birlikte kullanılarak yapılan ilk çalışma olma açısından önemli görülmektedir.

\section{Yöntem}

\section{Araştırmanın Modeli}

Nicel ve nitel verilerin bir arada kullanıldı̆̆ı karma yöntemin benimsendiği bu araştırmada, Ortaöğretim 10. Sınıf Kimya Dersi Öğretim Programı öğretmen görüşlerine başvurularak değerlendirilmiştir. Karma Yöntem Araştırmaları (mixed method researchs) hem nicel, hem de nitel verilerin tek bir çalışma içinde toplanması ve analiz edilip sunulmasına odaklanmaktadır. Veri toplamada nicel ve nitel verilerin aynı zamanda toplandığı, karma 
yöntem stratejilerinden Eşzamanlı Yuvalanma Stratejisi (concurrent nested strategy) benimsenmiştir (Creswell, Plano Clark, Gutmann \& Hanson, 2003).

\section{Çalışma Grubu}

Araştırmanın çalışma grubunu 2011 yılında Balıkesir il merkezi ve ilçelerindeki tüm resmi ortaöğretim kurumlarında görev yapan kimya öğretmenleri oluşturmuştur. Çalışma grubunda toplam 84 resmi ortaöğretim kurumunda 156 kimya öğretmeni bulunmaktadır. Çalışma grubunda bulunan 156 kimya öğretmenine anket uygulanmış, 10 kimya öğretmeni ile de görüşmeler yapılmıştır.

\section{Veri Toplama Araçları}

Anket

Er tarafından 2006 yılında geliştirilen ölçek, kimya dersine göre uyarlandıktan sonra alan uzmanları, eğitim bilimleri uzmanları ve kimya öğretmenleri görüşleri çerçevesinde ve literatür taraması sonucunda yeniden yapılandırılmıştır. Anket genel amaçlar, kazanımlar, etkinlikler, ölçme ve değerlendirme başlıkları altında programda yer alan ifadelerden oluşturulmuştur. Ankette "Genel Amaçlara" yönelik görüşleri belirlemek amaciyla sekiz ifadeye yer verilmiştir. Kazanımlar başlığı altında ise "Bilimsel Süreç Becerileri Kazanımlarına" ilişkin 11, "Kimya-Teknoloji-Toplum-Çevre Kazanımlarına" ilişkin 10, "İletişim-Tutum ve Değer Kazanımlarına" ilişkin yedi ifade yer almıştır. Kimya İçerik Kazanımları içerisinden "kritik" olarak belirlenen 45 kazanım ifadesine ankette yer verilmiştir. Programın Etkinliklerine yönelik görüşler 16, etkinliklerin uygulanmasında öğretmenler tarafından kullanılan Öğretim Yöntem ve Tekniklerine ilişkin görüşler yedi, Araç-Gereçlere ilişkin görüşler ise sekiz ifade ile belirlenmeye çalışılmıştır. Programın Değerlendirme öğesine ilişkin görüşlerin belirlenmesinde 10, değerlendirme sürecinde öğretmenler tarafından kullanılan Ölçme Araçlarına yönelik görüşlerin belirlenmesinde ise 12 ifadeye yer verilmiştir.

Ankette Genel Amaçlara, Etkinliklere ve Ölçme Değerlendirmeye yönelik görüşler Hiç Katılmıyorum-Çok Az Katılıyorum-Kısmen Katılıyorum-Büyük Ölçüde KatılıyorumTamamen Katılıyorum şeklinde beşli; Kazanımlara İlişsin görüşler Hiç Biri KazanamamıştırÇok Azı Kazanmıştır-Bazıları Kazanmıştır-Çoğu Kazanmıştır-Tümü Kazanmıştır şeklinde beşli; etkinliklerin uygulanmasında öğretmenler tarafından kullanılan Öğretim Yöntem ve Teknikleri ile Araç-Gereçler yanında değerlendirme sürecinde öğretmenler tarafından 
kullanılan Ölçme Araçlarına yönelik görüşler ise Hiç-Az-Sık-Çok Sık şeklinde dörtlü Likert tipinde ifadelerden oluşmaktadır.

\section{Görüşme Formu}

Araştırmada öğretmen görüşlerini belirlemek amacıyla standartlaştırılmış bir görüşme formu hazırlanmıştır. Görüşme formu hazırlanırken öncelikle alt problemlerden hareketle literatür taraması yapılmış ve yönlendirici olmayan, amaca uygun, kolay anlaşılabilecek tarzda sorular belirlenmeye çalışılmıştır. Daha sonra soruların yanlış anlaşılması veya anlaşılamaması gibi ihtimaller karşısında kullanılabilecek alternatif sorular yazılmıştır. Ayrıca görüşülen öğretmenlerin soruyu daha iyi anlamasına yardımcı olmak, daha ayrıntılı yanıtlara ulaşabilmek ve görüşme sürecini kontrol altında tutabilmek amacıyla sondalara da görüşme formunda yer verilmiştir. Oluşturulan görüşme formu dört alan uzmanı, beş eğitim bilimleri uzmanı ve beş kimya öğretmenin görüşüne sunulmuştur. Uzman görüşleri doğrultusunda görüşme soruları, alternatif sorular ve sondalar üzerinde gerekli düzeltmeler yapılmıştır. Asıl uygulama Balıkesir merkezde görev yapan kimya öğretmenleri ile gerçekleştirileceğinden, düzeltmeler sonucunda oluşturulan formun işlerliğini belirlemek amacıyla görüşme formunun deneme uygulaması, Balıkesir iline bağlı ilçelerde görev yapan 10 kimya öğretmeni ile gerçekleştirilmiştir.

\section{Verilerin Analizi ve Yorumu}

Araştırmanın alt problemlerini yanıtlayabilmek üzere uygulanan anketten elde edilen veriler SPSS 17 paket programı kullanılarak analiz edilmiştir. Verilerin dağılımlarını yorumlamak için frekans dağılımı (f) ve yüzde dağılım (\%) kullanılmıştır. Görüşmeden elde edilen veriler ise içerik analizi kullanılarak yorumlanmıştır. İçerik analizinin başlangıcında, araştırmanın alt problemleri ve kavramsal çerçevesi dikkate alınarak okunan veriler kodlanmıştır. Daha sonra oluşturulan kodlar arasındaki ortak yönler bulunmuş buna göre birbiriyle ilişkili olan kodlar bir araya getirilerek temalar oluşturulmaya çalışılmıştır. Görüşme yoluyla elde edilen veriler, ortaya çıkarılan kod ve temalara göre düzenlendikten sonra okuyucunun anlayabileceği biçimde tanımlanmış ve açıklanmıştır. Analizin son aşaması olan bulguların yorumlanması sırasında, benzer görüşler bir araya getirilmiş ve bulgular arasındaki ilişkiler açıklanarak, neden-sonuç ilişkileri kurulmuştur. 


\section{Bulgular ve Yorumlar}

\section{Genel Amaçlara İlişkin Öğretmen Görüşlerini Yansıtan Bulgular ve Yorumlar}

10.Sınıf Kimya Dersi Öğretim Programının genel amaçlarına ilişkin öğretmen görüşleri incelendiğinde, "Hiç Katılmıyorum”, “Çok Az Katılıyorum” ve "Kısmen Katılıyorum" ifadeleri birlikte yorumlandığında, öğretmenlerin \%88.3'ünün "Programın amaçları, öğrencilere kazandırılabilecek düzeydedir”, \%82'sinin "Programda, psikomotor alanla ilgili yer alan amaçlar yeterlidir” ve \%81.3'ünün "Programda, duyuşsal alanla ilgili yer alan amaçlar yeterlidir” genel amaçlarının gerçekleştirilmesinde sorun yaşadıkları; "Büyük Ölçüde Katılıyorum" ve "Tamamen Katılıyorum” ifadeleri birlikte yorumlandığında ise öğretmenlerin \%33.6'sının "Programın amaçları, anlaşılabilir bir dille ifade edilmiştir", \%28.9'unun "Programın amaçları, birbirini tamamlayıcı niteliktedir" ve \%27.3'ünün "Programın amaçları, birbirini desteklemektedir" genel amaçlarının gerçekleştirilmesinde sorun yaşamadıkları yönünde görüş bildirdikleri gözlenmektedir.

Öğretmenlerin en çok katıldıklarını belirttikleri genel amaçların yüzdelerine bakıldığında (\%27.3 ile \%33.6 arası), bu oranların çok yüksek olmadığı görülmektedir. Bu sonuç bize aslında öğretmenlerin genel amaçlarla ilgili ifadelerde sorun yaşadıklarını göstermektedir.

\section{Kazanımlara İlişkin Öğretmen Görüşlerini Yansıtan Bulgular ve Yorumlar}

Bilimsel Süreç Becerileri (BSB) Kazanımları

Öğretmenlerin 10.Sınıf Kimya Dersi Öğretim Programının bilimsel süreç becerileri kazanımlarına ilişkin görüşleri incelendiğinde, "Hiçbiri Kazanamamıştır”, "Çok Azı Kazanmıştır" ve "Bazıları Kazanmıştı»” ifadeleri birlikte yorumlandığında, öğretmenlerin \%83.5'inin "Deney yapabilme becerisi kazanır; hazır deney verilerini yorumlayarak genellemelere ulaşır” ve \%78.9'unun “Gözlem, deney ve araştırma ile ulaştığı sonuçları matematiksel ve sözel olarak ifade eder" kazanımlarının öğrenciler tarafindan kazanılmasında sorun olduğu yönünde görüş belirttikleri; “Çoğu Kazanmıştır” ve "Tümü Kazanmıştır” ifadeleri birlikte yorumlandığında ise öğretmenlerin \%40.7'sinin "Deneysel çalışma sırasında güvenlik kurallarına uyar” ve \%39'unun “Ölçülebilir büyüklükleri uygun birimlerle ifade eder" kazanımlarını öğrencilerin en çok ulaştığı kazanımlar olarak gördükleri ortaya çıkmaktadır. 
Bulgular, öğretmenlerin oldukça önemli bir kısmının öğrencilerin deney yapabilme ve deney sonuçlarını yorumlayabilme becerisi kazanmadıklarını düşündüklerini göstermektedir. Öğretmenlerin deneysel çalışma ile ilgili kazanım ifadesine \%40.7 gibi düşük bir oranda olumlu yanıt vermeleri de öğretim sürecinde yeterince deney yapılmadığ için öğrencilerin bu kazanımlara ulaşamadığı şeklinde yorumlanabilir. Diğer taraftan, öğretmenlerin büyük bir bölümünün öğrencilerin deney yapabilme becerisi kazanmadıklarını (\%83.5) düşündükleri halde, deneysel çalışma sırasında güvenlik kurallarına uyma ile ilgili kazanım ifadesine ilişkin düşük bir oranda (\%40.7) da olsa olumlu görüş belirtmeleri düşündürücüdür.

\section{Kimya-Teknoloji-Toplum-Çevre (KTTÇ) Kazanımları}

10.Sınıf Kimya Dersi Öğretim Programının kimya-teknoloji-toplum-çevre kazanımlarına ilişkin öğretmen görüşleri incelendiğinde, "Hiçbiri Kazanamamıştır”, "Çok Azı Kazanmıştır" ve "Bazıları Kazanmıştır" ifadeleri birlikte yorumlandığında, öğretmenlerin \%82.1'inin "Bilimsel gelişmelerin toplumsal ve sosyal maliyetini irdeler", \%79'unun "Kimyadaki gelişmelerin ekonomik, sosyal, politik ve moral değerlere etkisini yorumlar” ve \%78.9'unun “Kimya dersinde öğrendiklerini günlük yaşamda karşılaştığı sorunları çözmede kullanır" kazanımlarının kazanılmasında sorun olduğunu belirttikleri; "Çoğu Kazanmıştır” ve “Tümü Kazanmıştır” ifadeleri birlikte yorumlandığında ise öğretmenlerin \%46.8'inin "Bilim ve teknolojideki gelişmelerin insanlar ve doğa üzerine olumsuz etkilerine örnekler verir", \%36'sının "Bilim ve teknoloji üzerine çalışma yapmanın önemini sorgular” ve \%35.9'unun "Kimya ile ilgili problemlerin çözümünde ve fiziksel olayları açıklamada öğrendiklerini kullanır” kazanımlarını öğrencilerin en çok ulaştıkları kazanımlar olarak ifade ettikleri gözlenmektedir.

Bulgular incelendiğinde, öğretmenlerin kimya dersinde öğrenilenlerin günlük yaşama aktarılmasına, bilimsel gelişmelerin ve kimyadaki gelişmelerin etkilerinin yorumlanmasına yönelik kazanım ifadelerine çoğunlukla olumsuz yanıtlar verdikleri görülmektedir. Öğretmenlerin öğrencilerin çoğu tarafından kazanıldığını ifade ettikleri kazanımlara ilişkin görüşlerinin yüzdelerine bakıldığında; oranların \%35.9 ile \%46.8 arasında olduğu yani çok yüksek olmadığı ve kimya-teknoloji-toplum-çevre kazanımlarının aslında yeterli düzeyde kazanılmadığı düşüncesi doğmaktadır.

İletişim, Tutum ve Değer (ITTD) Kazanımları

10.Sınıf Kimya Dersi Öğretim Programının iletişim, tutum ve değer kazanımlarına ilişkin öğretmen görüşleri incelendiğinde, "Hiçbiri Kazanamamıştır” ve "Çok Azı 
Kazanmıştı»" ifadeleri birlikte yorumlandığında, öğretmenlerin \%35.1'inin “Öğrenmek için ödül beklemez; öğrenmenin kendisini bir ödül sayar ve ömür boyu öğrenmeye isteklidir” ve \%30.5'inin "Evreni ve hayatı anlamada bilimin yol göstericiliğini özümser; bilimin öncelik aldığı durumları, demokrasinin öncelik aldığı durumlardan ayırt eder” kazanımlarının kazanılmadığını belirttikleri; “Bazıları Kazanmıştır”, “Çoğu Kazanmıştır” ve “Tümü Kazanmıştır” ifadeleri birlikte yorumlandığında ise öğretmenlerin \%82.9'unun "Çevre sorunlarına karşı duyarlıdır” ve \%82.8'inin “İş birliği yaparak çalışmaya gönüllüdür” kazanımlarında sorun yaşanmadığını ifade ettikleri ortaya çıkmaktadır.

Bulgular öğretmenlerin büyük bir kısmının, öğrencilerin çevre sorunlarına karşı duyarlı ve iş birliği yaparak çalışmaya istekli olduklarını düşündüklerini göstermektedir. Öğretmenlerin olumsuz görüş bildirdikleri kazanım ifadeleri, sadece kimya eğitiminde değil bütün alanlardaki eğitim yaşantılarında gösterilmesi beklenen tutum ve becerilerdir. $\mathrm{Bu}$ bağlamda kazanılması beklenen tutum ve becerilerin, öğrencilerin tüm öğrenim hayatları süresince kazanabilecekleri türden oldukları söylenebilir.

\section{Kimya İçerik Kazanımları}

Öğretmenlerin 10.Sınıf Kimya Dersi Öğretim Programının kimya içerik kazanımlarına ilişkin görüşleri incelendiğinde, "Hiç Biri Kazanamamıştır" ve "Çok Azı Kazanmıştır" ifadeleri birlikte yorumlandığında, öğretmenlerin \%39.9'unun “Işın kuantumlarının (fotonların) enerjisi ile dalga nicelikleri arasında ilişki kurar”, \%39.1'inin "Atom altı tanecikler üzerinde yapılan ölçmelerdeki belirsizliğin önemini açıklar” ve \%37.5'inin "Bohr modelinin temel varsayımlarını ve hidrojen atomundaki elektronun toplam enerjisini ifade eder" kazanımlarının kazanılmasında sorun olduğunu belirttikleri; "Bazıları Kazanmıştır”, “Çoğu Kazanmıştır” ve “Tümü Kazanmıştır” ifadeleri birlikte yorumlandığında ise öğretmenlerin \%94.5'inin "Elementlerin elektron dizilimleri ile periyodik sistemdeki yerleri arasında ilişki kurar", \%93.8'inin "Elektron dizilimleri $s$ orbitali ile biten elementlerin özelliklerini açıklar”, \%93'ünün "Metalik ve ametalik özelliklerin periyotlardaki ve gruplardaki seyrini açıklar", "p-Bloku elementlerinde grup özelliklerini listeler” ve “İyonik bağlı bileşiklerin genel fiziksel özelliklerini bağın niteliği üzerinden açıklar" kazanımlarını öğrencilerin en çok ulaştığı kazanımlar olarak ifade ettikleri görülmektedir.

Bulgular incelendiğinde, öğrencilerin yeterli düzeyde kazanamadı̆̆ı belirtilen içerik kazanımlarının soyut kavramlar içerdiği görülmektedir. Johnstone (1991), kimya konularının genel olarak maddenin içyapısıyla ilgili olduğundan birçok soyut kavramı içerdiklerini 
belirtmektedir. $\mathrm{Bu}$ nedenle öğrencilerin kimya dersindeki kavramları zihinlerinde yapılandırmaları, diğer doğa bilimlerindeki kavramları zihinlerinde yapılandırmalarından çok daha zor ve karmaşıktır. Ayrıca öğretmenlerin öğrenciler tarafından ulaşıldığını belirttikleri kazanımların yüzdelerinin yüksek bir oranda olması (\%93-\%94.5) önemli bir bulgu olarak görülebilir.

\section{Etkinliklere İlişkin Öğretmen Görüşlerini Yansıtan Bulgular ve Yorumlar}

Öğretmenlerin 10.Sınıf Kimya Dersi Öğretim Programının etkinliklerine ilişkin görüşleri incelendiğinde, "Hiç Katılmıyorum”, "Çok Az Katılıyorum” ve "Kısmen Katılıyorum" ifadeleri birlikte yorumlandığında, öğretmenlerin \%83.6'sının "Programda Kimya öğretimi için önerilen yöntem ve teknikler, sınıf düzeyine uygun niteliktedir”, \%81.3'ünün “Program, sınıf ortamında farklı etkinliklerin aynı anda uygulanmasına uygundur" ve \%80.4'ünün "Programda Kimya öğretimi için önerilen yöntem ve teknikler, Kimyayı sevdirici niteliktedir" ifadeleri hakkında olumsuz görüş belirttikleri; “Büyük Ölçüde Katılıyorum” ve “Tamamen Katılıyorum” ifadeleri birlikte yorumlandığında ise öğretmenlerin \%50'sinin "Programda yer alan etkinlikler konularla tutarlıdır", \%47.6'sının “Programda etkinlikler ayrıntılı olarak yer almaktadır” ve \%45.3'ünün “Programda kullanılması önerilen araç-gereçler konulara uygundur" ifadelerine çoğunlukla katıldıkları gözlenmektedir.

Etkinliklere ilişkin bulgular bir bütün olarak incelendiğinde, öğretmenlerin büyük bir kısmının etkinliklerin uygulanmasında önerilen yöntem ve teknikleri sınıf düzeyine uygun bulmadıkları gözlenmektedir. Ayrıca, öğretmenlerin çoğunluğu, önerilen yöntem ve tekniklerin Kimyayı sevdirici nitelikte ve programın farklı etkinliklerin aynı anda uygulanmasına uygun olmadığı yönünde görüş belirtmektedirler. $\mathrm{Bu}$ durum öğretmenlerin anlatım ve soru-cevap gibi öğretmen merkezli yöntemleri kullanmalarına neden olmaktadır.

\section{Öğretim Yöntem ve Tekniklerine İlişkin Bulgular ve Yorumlar}

Öğretmenlerin 10.Sınıf Kimya Dersi Öğretim Programında yer alan öğretim yöntem ve tekniklerinin ne sıklıkta kullanıldığına ilişkin görüşleri incelendiğinde, öğretmenlerin çoğunlukla "soru-cevap" (sık \%46.9, çok sık \%48.4), "problem çözme” (sık \%42.2 çok sık \%52.3) ve "anlatım” (sık \%39.8, çok sık \%51.6) yöntemlerini; en az ise “deney yapma” (hiç \%20.3, az \%69.5) yöntemini kullandıkları görülmektedir. 
Kimya dersinde "deney yapma" yönteminin en az kullanılan yöntem olması düşündürücüdür. $\mathrm{Bu}$ durumun, etkinliklerin deney ağırlıklı olmaması, ders saatlerinin yetersizliği, araç-gereç yetersizliği nedeniyle kimya laboratuarlarının etkili şekilde kullanılamaması ve öğretmenlerin programı yetiştirme kaygısından kaynaklandığı söylenebilir. Bu bağlamda, kazanılan bilgilerin deneylerle pekiştirilmesi, teorik olarak verilen kural ve prensiplerin deneylerle nasıl çıkarıldığının gösterilmesi öğrencilerin derse yönelik ilgilerini artıracak ve öğrenmede başarı ve hatırlama düzeyini yükseltecektir (Kulik, 1985; Hounshell \& Hill, 1989; Greenbowe, Burke \& Windschitl, 1998; Peker \& Mirasyedioğlu, 2003).

$\mathrm{Bu}$ araştırma sonucunda ortaya çıkan bulguların benzeri, Özcan (2000), Karaaslan (2007), Özden (2007) ve Barın (2009) tarafından yapılan araştırmalarda da ortaya çıkmıştır. Özcan (2000), kimya eğitiminde kullanılan öğretim yöntemlerinin ve araçların kullanılma sıklığını saptamayı amaçladı̆̆ı araştırmasında; kimya öğretmenlerinin düz anlatım yöntemi yanında soru cevap ve problem çözme yöntemlerini kullandıkları; grup tartışması, gezi gözlem ve deney yapma yöntemlerini ise derslerde hemen hemen hiç kullanmadıkları sonuçlarına ulaşmıştır. Karaaslan'ın (2007), Van ili ve çevre ilçelerdeki liselerde görev yapan kimya öğretmenleriyle gerçekleştirdiği çalışmasında da öğretmenler en çok anlatım ve sorucevap yöntemlerini kullandıklarını ifade etmişlerdir. Özden'in (2007) çalışmasında, Adıyaman ve Malatya ili merkez ortaöğretim okullarında görev yapan kimya öğretmenlerinin öğretim sürecinde karşılaştıkları sorunların belirlenmesi ve değerlendirilmesi amaçlanmıştır. Araştırma sonucunda, öğretmenlerin \%68'i çoğunlukla düz anlatım ve soru-cevap tekniklerini kullandıklarını belirtmişılerdir. Barın (2009) tarafından, kimya öğretiminin sorunlarını belirlemek ve değerlendirmek amacıyla yapılan araştırmada da öğretmenlerin en fazla sorucevap, problem çözme ve anlatım yöntemlerini kullandıkları görülmüştür.

\section{Araç-Gereçlere İlişkin Bulgular ve Yorumlar}

Öğretmenlerin 10.Sınıf Kimya Dersi Öğretim Programında yer alan araç-gereçlerin ne sıklıkta kullanıldığına ilişkin görüşleri incelendiğinde, “ders kitabı” (sık \%40.6, çok sık \%37.5) öğretmenlerin çoğunlukla kullandıkları; “mikroskop” (hiç \%78.1, az \%18.8), "jilet” (hiç \%65.6, az \%28.9) ve "büyüteç" (hiç \%64.8, az \%30.5) ise en az kullandıkları araçgereçler olarak gözlenmektedir.

Bulgular incelendiğinde, öğretmenlerin öğretim sürecinde en çok ders kitabını, en az ise mikroskobu kullandıkları görülmektedir. $\mathrm{Bu}$ bulgu, öğretmenlerin yukarıda yer alan yöntem ve tekniklerin kullanılmasıyla ilgili olarak belirtmiş oldukları görüşler ile paralellik 
göstermektedir. Yukarıda öğretim yöntem ve tekniklerine ilişkin bulgularda "Deney yapma" yönteminin öğretmenlerin en az kullandıkları yöntem olduğu belirlenmişti bu nedenle; “mikroskop”, “jilet” ve "büyüteç” gibi araç-gereçlerin kullanımına ilişkin olumsuz görüş belirtilmesi beklenen bir sonuçtur.

\section{Değerlendirme Boyutuna İlişkin Öğretmen Görüşlerini Yansıtan Bulgular ve Yorumlar}

Öğretmenlerin 10.Sınıf Kimya Dersi Öğretim Programının değerlendirme boyutuna ilişkin görüşleri incelendiğinde, "Hiç Katılmıyorum”, "Çok Az Katılıyorum” ve "Kısmen Katılıyorum” ifadeleri birlikte yorumlandığında, öğretmenlerin \%82.1'inin “Geleneksel ve performansa dayalı değerlendirme araçları programa uygun niteliktedir" ve \%80.4'ünün “Değerlendirme sadece sınıf içi değil sınıf dışı çalışmalara da dayanmaktadır” ifadelerine katılmadıkları; "Büyük Ölçüde Katılıyorum" ve "Tamamen Katılıyorum” ifadeleri birlikte yorumlandığında ise öğretmenlerin \%39.1'inin "Değerlendirme içerikle tutarlıdır" ve \%39'unun "Değerlendirme, kazanımlar ile tutarlıdır" ifadelerine çoğunlukla katıldıkları gözlenmektedir.

Değerlendirme boyutuna ilişkin bulgular bir bütün olarak ele alındığında, öğretmenlerin çoğunluğunun değerlendirmenin içerik ve kazanımla tutarlı olduğunu ve sınıf içi çalışmalara dayandığını düşündükleri görülmektedir. Öğretmenlerin değerlendirme boyutuna yönelik olarak belirtmiş oldukları en olumsuz görüş, geleneksel ve performansa dayalı değerlendirme araçlarının programa uygun nitelikte olmadığına yönelik görüşlerden oluşmaktadır.

\section{Değerlendirme Araçları}

Öğretmenlerin 10.Sınıf Kimya Dersi Öğretim Programında yer alan değerlendirme araçlarının hangisinin, ne sıklıkta kullanıldığına ilişkin görüşleri incelendiğinde, öğretmenlerin çoğunlukla kullandıklarını belirttikleri değerlendirme araçları "kısa cevaplı" sorular (sık \%60.2, çok sık \%33.6), "boşluk doldurma" (sık \%64.8, çok sık \%10.9) ve "çoktan seçmeli” (sık \%49.2, çok sık \%28.9) test; en az kullandıklarını belirttikleri değerlendirme araçları ise "poster” (hiç \%31.3, az \%54.7), "broşür” (hiç \%31.3, az \%51.6) ve “gözlem-takip formu” (hiç \%28.1, az \%55.5) olarak gözlenmektedir.

Değerlendirme araçlarına ilişkin öğretmen görüşleri incelendiğinde, öğretmenlerin en çok "kısa cevaplı" sorular; en az "poster" türündeki değerlendirme araçlarını kullandıkları görülmektedir. Öğretmenlerin büyük bir kısmının, kazanımların ulaşılabilirliğini ölçmede çoktan seçmeli test kullanmasının, üniversite giriş sınavında çoktan seçmeli testin 
kullanılmasından kaynaklandığı düşünülmektedir. Öğretmenlerin poster, broşür, gözlem-takip formu gibi performansa dayalı değerlendirme araçlarını az kullanılmasının nedeni, bu araçların kullanım alanları ile yeterince bilgi sahibi olmamaları ile açıklanabilir. Ayrıca öğretmenlerin değerlendirmeyi nasıl algıladıkları ve tecrübeleri de farklı değerlendirme araçlarını kullanmalarında etkili olabilir. Schmidt \& Brosnan (1996) tarafından yapılan araştırmada, öğretmenlerin \%18'den azının alternatif değerlendirme araçlarını kullandıkları görülmüş̧ür. Öğretmenlerin çoğu kendilerine hizmet içi eğitim verilmesinin, bu tür araçların nasıl uygulanacağının görülmesinin ve zaman gibi etmenlerin söz konusu araçları kullanmalarını teşvik edeceğini belirtmiştir.

\section{Görüşme Formuyla Elde Edilen Öğretmen Görüşleri}

\section{Programla İlgili Bilgilenme Yolu ve Düzeyi}

Araştırmaya katılan ögretmenlerin çok azı, program hakkında bilgilendirildiklerini ve bu bilgilendirmenin programın uygulanmaya başlamasından sonra olduğunu ifade etmektedirler. Programla ilgili olarak bilgilendirildiklerini ifade eden öğretmenler kendilerini bilgilendiren kişileri yeterli bulmamakta ve bilgilendirilme düzeylerinin yetersiz olduğunu düşünmektedirler. Öğretmenlerin büyük çoğunluğu bu konudaki eksikliklerini kendi çabalarıyla gidermeye çalıştıklarını belirtmişlerdir. Bu konuda öğretmenlerden bazılarının görüşleri şöyledir: "Değişen Kimya programıyla ilgili hizmet içi eğitim programına katılmadım. Zümre toplantılarından, MEB yayınlarından takip ediyorum” (K.Ö.-4)”. "Programla ilgili bir hizmet içi eğitim yapılmadı. Ben bu programı ancak internet üzerinden elde edebildim (K.Ö.-2)”.

\section{Programda Yer Alan Kazanımlar}

Araştırmaya katılan öğretmenlerin çoğu, programda yer alan kazanımların öğrencilerin gelişim düzeyine ve hazır bulunuşluğuna uygun olmadığını ayrıca kazanımların okul türlerine göre yapılandırılması gerektiğini belirtmektedirler. Genel olarak programda yer alan kazanımların aşamalılığı konusunda olumsuz görüşlere sahip olan öğretmenlerin yanında, konuyla ilgili olumlu görüşlere sahip olan öğretmenlerin de olduğu söylenebilir. Öğretmenlerin tamamı, programda yer alan kazanımların çok fazla ve ayrıntılı olduğunu, bu nedenle de gerçekleşme düzeylerinin yeterli olmadığını düşünmektedirler. Araştırmaya katılan öğretmenler, özellikle “Atomun Yapısı” ünitesinde yer alan kazanımların fizik konularını fazlasıyla kapsadığını ve öğrenciler tarafından algılanmasının zor olduğunu ifade 
etmektedirler. Örneğin bir öğretmen düşüncelerini aşağıdaki cümlelerle ifade etmiştir: "Bohr Atom Modelinde hidrojenimsi atomların veya iyonların, elektronların davranışlarını, fotoelektrik olayı lise sonda bile fizikçilerin anlatması biraz zor iken biz bunları 10.sınıfta anlatmak zorunda kallyoruz (K.Ö.-3)”.

\section{Programda Önerilen Etkinlikler}

Programın etkinliklerine ilişkin öğretmen görüşlerinin belli noktalarda odaklandığı görülmektedir. Bunlar; etkinliklerin uygulama ağırlıklı olmaması, etkinlik örneklerinde günlük hayatla yeteri kadar ilişki kurulmaması, etkinliklerin farklı yöntem ve tekniklerin bir arada kullanılmasına uygun olmaması, etkinliklerde önerilen araç-gereçlerin öğrenmenin kalıcılığını sağlamada yetersiz olması, etkinliklerde farklı okul türlerindeki öğrencilerin ilgi ve ihtiyaçlarının dikkate alınmamış olması olarak sıralanabilir. Öğretmenlerden bazılarının bu konudaki görüşleri şöyledir: "Günlük yaşamla ilişkili örnekler verilmiş ama dikkat çekici örnekler değil. Ben örnekler sunuyorum ama sunduğum örneklerde beni program değil, testler yönlendiriyor (K.Ö.-7)”. "Programda önerilen yöntem ve teknikler kazanımların kazandırılmasında yeterli değil. Kendim yeni yöntem ve tekniklere, araç-gereçlere başvurmak durumunda kallyorum (K.̈̈.-1)”.

\section{Programda Önerilen Değerlendirme Durumlart}

Yapılan görüşmelerde öğretmenler, programda yer alan ölçme ve değerlendirme örneklerini yetersiz gördüklerini ve önerilen değerlendirme örneklerinin benzerlerini ölçmedeğerlendirme etkinliklerinde kullandıklarında da öğrencilerin ezberciliğe yöneldiklerini gördüklerini ifade etmişlerdir. Bu nedenle öğretmenler, daha çok kendilerinin geliştirdikleri soruları kullanmayı tercih ettiklerini ayrıca üniversiteye giriş sınavında kullanılan ölçme araçlarıyla programda yer alan değerlendirme örnekleri arasında uyumsuzluk olduğunu düşündüklerini ifade etmişlerdir. Öğretmenlerin konuyla ilgili soruya verdikleri yanıtlardan bazıları aşağıda şöyledir: "Verilen örnekler sadece çocuğu oyalamaya yönelik. Tanımlar verip eşleştirme yaparak neyin kalitesini ölçebiliriz ki? Çocuğa niye yağmurun cama vurduğunu sorsanız cevap alamıyorsunuz. Çünkü bu tip sorular soramıyoruz. Verilen ölçme değerlendirme etkinlikleri yorum gerektirmiyor. Programda yer alan ölçme değerlendirme üniversiteye giriş sınav sistemi ile hiç uyumlu değil (K.Ö.-10)”. "Programda önerilen değerlendirme örnekleri yeterli değil. Mesela boşluk doldurma soruları en az yirmi kazanımla ilişkili olmalı. Doğru yanlış tipinde sorular da olabilir. Boşluk doldurmanın fazla olması 
çocuğu ezbere yöneltiyor. Verilen örnekler, istenilen kazanımları kazandırmada yeterli olmadığı için kendim sorular hazırlıyorum (K.Ö.-6)’”.

\section{Programın Uygulanabilirliği}

Öğretmenlerin programın uygulanabilirliğine ilişkin görüşleri incelendiğinde, öğretmenlerin programın uygulanabilir olmadığı görüşünde birleştikleri görülmektedir. Ders saatlerinin yetersizliğini, kazanımların çok fazla ve konuların 10.sınıf düzeyinin üzerinde olmasını da bu durumun nedenleri olarak göstermektedirler. Ayrıca öğretmenler, öğretim sürecini uygulamada, kendilerine programdan çok ders kitaplarının ve tecrübelerinin yardımcı olduğu konusunda görüş bildirmektedirler. Bu konuda öğretmen görüşlerinden bazıları şöyledir: "Program Fen Lisesi için bile çok ă̆ır. Birkaç öğretmen dışında ilimizde programı uygulayabilen öğretmen yok (K.Ö.-10)”. “Temelde güzel hazırlanmış olmasına rağmen uygulanabilirliği açısından ders saatleri yetersiz (K.Ö.-1)”.

\section{Programın Güçlü Yanları}

Öğretmen görüşmelerinden elde edilen veriler incelendiğinde, öğrencinin günlük hayatla bağlantı kurmasını sağlamasının, konuların bilimsel olarak sunulmasının, öğrencileri sorgulamaya yöneltmesinin, kendi içerisinde kazanımlarıyla, etkinlikleri ve değerlendirme boyutu ile tutarlılık göstermesinin programın olumlu yönleri olarak sıralandığı görülmektedir. Öğretmenler, programın güçlü yanlarına ilişkin görüşlerini şu cümlelerle dile getirmişlerdir: "Konuları bilimsel olarak anlatıyor. Bilimsel olarak anlatmasından memnunum. Sonuçta kimya bir bilimdir (K.Ö.-7)”. "10.sınıf kimya dersi programı kendi içinde etkinlikleriyle, kazanımlarıyla, değerlendirmeleriyle uyumlu (K.Ö.-8)’”.

\section{Programın Zaylf Yanları}

Programın zayıf yanlarına ilişkin öğretmen görüşlerinden elde edilen veriler incelendiğinde, öğretmenlerin genel olarak; programın anlayışıyla üniversiteye giriş sınavı arasında bir uyum sorununun olmasını, konuların öğrencinin hazır bulunuşluğunu ve gelişim düzeyini dikkate almamasını ve öğretmeni bilgi bakımından zorlamasını, kazanım sayısının ders saatlerinde yetiştirilemeyecek kadar çok olmasını, etkinlik ve değerlendirme örneklerinin az sayıda olmasını, programın okul ve çevre şartlarına göre kazanım, etkinlik ve değerlendirme boyutlarında yapılacak değişiklikler karşısında esnek olmamasını programın zayıf yanları olarak sıraladıkları görülmektedir. Öğretmenler bu konudaki görüşlerini şu şekilde ifade etmişlerdir: “10. sınıf kimya programı meslek liselerindeki öğrenci hazır 
bulunuşluk düzeyinin üzerinde (K.Ö.-8)". "Program üzerinde çevre şartları vb. gibi nedenlerden dolayı değişiklik yapmak mümkün değil. Çünkü yapılan YGS, LYS sinavları bu programları hedef alarak hazırlanıyor. O yüzden ben programın herhangi bir bölümü çocuğa uygun değil, bunu öğrenmesin diyemem, çünkü sinavda sorulabilir (K.Ö.-6)”.

\section{Programa İlişkin Öneriler}

Öğretmenlerin programa ilişkin önerileri incelendiğinde, kazanımların öğrencilerin seviyelerinin üzerinde olduğu bu nedenle gözden geçirilerek öğrenci seviyesine uygun hale getirilmesi gerektiğinin vurgulandığı görülmektedir. Öğretmenlerin hemen hemen hepsi dersin süresinin kısa olması ve kazanımların çok fazla olması nedeniyle derste farklı yöntemler kullanamadıklarını ama laboratuarlarda gerçekleştirilecek uygulama çalışmalarının dersin daha etkili hale getirilmesine yardımcı olacağını belirtmektedirler. Öğretmenler ayrıca etkinlik örneklerinin arttırılması ve bu örneklerin öğrencilerin günlük yaşamlarından olması gerektiğini de vurgulamaktadırlar. Programın ölçme-değerlendirme durumlarına ilişkin olarak getirilen öneriler incelendiğinde; dersin özelliği gereği ölçme değerlendirmenin daha çok öğrencilerin yorum yapmasını sağlayıcı türdeki uzun cevaplı sorulardan oluşması gerektiği ortaya çıkmaktadır. Öğretmenlerden bazıları görüşlerini şu cümlelerle ifade etmişlerdir: “Kazanımlarla ders saatleri tutarsız. Ders saatleri üç saat teorik ve bir saat laboratuar gibi yeniden düzenlenmeli. Etkinliklerde laboratuar uygulamalarına ăğrlık verilmeli. Öğrenciler en az bir deney yapabilmeli. Üniversite ögrencileri ile okullar ortak çalışmall, öğrenciler kimya derslerinde özellikle laboratuarda ögretmenlere yardımcı olmalı (K.Ö.-1)”. "Değerlendirme teknikleri bilimsel anlamda düşünülerek hazırlanmall, dĕgerlendirme örnekleri ve kazanımlar zeka tiplerine göre yapılandırılmalı. Kazanımların sayısı azaltılmalı. Kazanımlar basitleştirilmeli. Etkinlikler, deney yapmaya ağırlık verecek şekilde düzenlenmeli. Ders saatleri arttırılmalı. Programlar teknik liselere göre ayrıca yapılmall. Öğretmenlere içerisinde kazanımlar, etkinlikler, değerlendirme örnekleri olan kllavuz kitaplar verilmeli. Öğretmen bunların içerisinden kendisi seçim yapabilmeli ve program öğretmene ve ögretmenin yapacă̆ de ğişikliklere karşı esnek olmalı (K.Ö.-4)”.

Çalışmada Değerlendirilen 03.06.2008 Tarihli Program ile 01.02.2013 Tarihinde Değişen Yeni Kimya Dersi Öğretim Programının Karşılaştırılmasına İlişkin Bulgular 
Milli Eğitim Bakanlığg Talim ve Terbiye Kurulu Başkanlığı'nın 01.02.2013 tarih ve 11 sayılı kararı ile Ortaöğretim Kimya Dersi (9, 10, 11 ve 12. Sınıflar) Öğretim Programı, 20132014 öğretim yılından itibaren 9. sınıflardan başlamak ve kademeli olarak uygulanmak üzere değiştirilmiştir. Her iki programda da bireylerde belirli bir kimya kültürü oluşturma amaciyla; veri toplama, analiz etme ve yorumlama, kimya bilgilerini kullanarak çevreyi ve hayatı sorgulama gibi bilimsel düşünme becerileri vurgulanmaktadır. Bunun yanı sıra, Temel Düzey Kimya Dersi Öğretim Programında, çalışmada değerlendirilen programdan farklı olarak kimyasal teknolojilerin günlük hayata yansımalarını yorumlama ve bilimsel bilgiyi kullanmada bilişim teknolojilerinden yararlanma gibi tutum ve becerilere de yer verildiği görülmektedir.

\section{Kazanımların Karşılaştırılması}

Programlarda yer alan ünitelere ait bilgiler (URL-1; URL-2) aşağıda Tablo 1'de sunulmuştur.

Tablo 1 Programlarda Yer Alan Ünitelerin Karşıllaştırılması

\begin{tabular}{|c|c|c|c|c|c|}
\hline \multicolumn{3}{|c|}{$\begin{array}{l}\text { Değerlendirilen Program } \\
\text { (2008 tarihli) }\end{array}$} & \multicolumn{3}{|c|}{$\begin{array}{c}\text { Temel Düzey Kimya Dersi Öğretim Program } \\
\text { (2013 tarihli) }\end{array}$} \\
\hline$\ddot{U}$ nite $A d l$ & $\begin{array}{l}\text { Kazanım } \\
\text { Sayısı }\end{array}$ & $\begin{array}{c}\text { Önerilen } \\
\text { Süre/Ders } \\
\text { Saati }\end{array}$ & Unite $A d \imath$ & $\begin{array}{l}\text { Kazanım } \\
\text { Sayısı }\end{array}$ & $\begin{array}{c}\text { Önerilen } \\
\text { Süre/Ders } \\
\text { Saati }\end{array}$ \\
\hline Atomun Yaptst & 33 & 16 & $\begin{array}{l}\text { Asitler, Bazlar } \\
\text { ve Tuzlar }\end{array}$ & 8 & 18 \\
\hline $\begin{array}{l}\text { Periyodik } \\
\text { Sistem }\end{array}$ & 18 & 12 & Karışımlar & 5 & 16 \\
\hline $\begin{array}{l}\text { Kimyasal } \\
\text { Türler Arası } \\
\text { Etkileşimler }\end{array}$ & 19 & 12 & $\begin{array}{l}\text { Endüstride ve } \\
\text { Canlılarda } \\
\text { Enerji }\end{array}$ & 13 & 20 \\
\hline $\begin{array}{l}\text { Maddenin } \\
\text { Hâlleri }\end{array}$ & 35 & 18 & $\begin{array}{l}\text { Kimya Her } \\
\text { Yerde }\end{array}$ & 13 & 18 \\
\hline Karışımlar & 18 & 14 & & & \\
\hline Toplam & 123 & 72 & Toplam & 39 & 72 \\
\hline
\end{tabular}

Tablo 1'de, Temel Düzey Kimya Dersi Öğretim Programında ünite sayısının beşten dörde, kazanım sayısının ise 123'ten 39'a düştüğü; buna rağmen kazanımların gerçekleştirilmesi için önerilen ders saatlerinin değişmediği görülmektedir. Böylece 2008 
tarihli programda daha önce 72 saatte 123 kazanımın gerçekleştirilmesi önerilirken; değişen programda 72 saatte 39 kazanımın gerçekleştirilmesi önerilmektedir.

\section{Etkinliklerin Karşılaştırılması}

Çalışmada değerlendirilen ortaöğretim kimya programında işleniş derinliği/etkinlik örnekleri başlığında altında; öğretim sürecinde uygulanabilecek etkinliklere, kullanılabilecek öğretim yöntem ve teknikleri ile araç-gereçlere ayrıntılı olarak yer verildiği görülmektedir. Temel Düzey Kimya Dersi Öğretim Programında ise kazanımlar ve açıklamalar başlığı altında, uygulanabilecek etkinliklere, kısmen de kullanılabilecek öğretim yöntem ve teknikleri ile araç-gereçlere yer verildiği görülmektedir. Programda problem çözme, deney yapma gibi öğrencilerin bilimsel ve üst düzey düşünme becerilerini geliştirici yöntem ve tekniklerin yer almadığg, etkinliklerin daha çok öğretmen merkezli olduğu göze çarpmaktadır.

\section{Değerlendirme Boyutunun Karşılaştırılması}

Çalışmada değerlendirilen programın ölçme ve değerlendirmeye bakış açısı ile değişen programın bakış açısı arasında benzerlik görülmektedir. Ancak, değerlendirilen programda ünite sonlarında yer alan değerlendirme örneklerine, Temel Düzey Kimya Programında yer verilmemiştir. $\mathrm{Bu}$ anlamda Temel Düzey Kimya Programının değerlendirme boyutu bakımından öğretmenlere yeterince ölçme değerlendirme örneği sunmadığı söylenebilir.

\section{Sonuç ve Tartışma}

Öğretmen görüşlerine göre, Ortaöğretim 10.Sınıf Kimya Dersi Öğretim Programında yer alan genel amaçlar birbirini tamamlayıcı ve destekler nitelikte olmanın yanında anlaşılabilir bir dille ifade edilmiştir. Ancak programda yer alan genel amaçlar öğrencilere kazandırılabilecek düzeyde olmadığı gibi psiko-motor ve duyuşsal alanla ilgili yer alan amaçlar da yeterli düzeyde değildir.

Öğretmen görüşlerine göre, öğrenciler tarafindan kazanılmasında en çok sorun yaşanan Bilimsel Süreç Becerileri Kazanımları, "Deney yapabilme becerisi kazanır; hazır deney verilerini yorumlayarak genellemelere ulaşır” ve “Gözlem, deney ve araştırma ile ulaştığı sonuçları matematiksel ve sözel olarak ifade eder"; en çok ulaşılan kazanımlar ise “Deneysel çalışma sırasında güvenlik kurallarına uyar” ve “Ölçülebilir büyüklükleri uygun birimlerle ifade eder" kazanımlarıdır.

Öğretmen görüşlerine göre, öğrenciler tarafindan kazanılmasında en çok sorun yaşanan Kimya-Teknoloji-Toplum-Çevre Kazanımları "Bilimsel gelişmelerin toplumsal ve 
sosyal maliyetini irdeler", "Kimyadaki gelişmelerin ekonomik, sosyal, politik ve moral değerlere etkisini yorumlar" ve "Kimya dersinde öğrendiklerini günlük yaşamda karşılaştığı sorunları çözmede kullanır"; en çok ulaşılan kazanımlar ise "Bilim ve teknolojideki gelişmelerin insanlar ve doğa üzerine olumsuz etkilerine örnekler verir”, "Bilim ve teknoloji üzerine çalışma yapmanın önemini sorgular" ve "Kimya ile ilgili problemlerin çözümünde ve fiziksel olayları açıklamada öğrendiklerini kullanır” kazanımlarıdır.

Öğretmen görüşlerine göre, öğrenciler tarafindan kazanılmasında en çok sorun yaşanan İletişim, Tutum ve Değer Kazanımları "Öğrenmek için ödül beklemez; öğrenmenin kendisini bir ödül sayar ve ömür boyu öğrenmeye isteklidir" ve "Evreni ve hayatı anlamada bilimin yol göstericiliğini özümser; bilimin öncelik aldığı durumları, demokrasinin öncelik aldığı durumlardan ayırt eder”; en çok ulaşılan kazanımlar ise “Çevre sorunlarına karşı duyarlıdır” ve “İş birliği yaparak çalışmaya gönüllüdür” kazanımlarıdır.

Öğretmen görüşlerine göre, öğrenciler tarafindan kazanılmasında en çok sorun yaşanan Kimya İçerik Kazanımları, "Işın kuantumlarının (fotonların) enerjisi ile dalga nicelikleri arasında ilişki kurar”, “Atom altı tanecikler üzerinde yapılan ölçmelerdeki belirsizliğin önemini açıklar" ve "Bohr modelinin temel varsayımlarını ve hidrojen atomundaki elektronun toplam enerjisini ifade eder"; en çok ulaşılan kazanımlar ise "Elementlerin elektron dizilimleri ile periyodik sistemdeki yerleri arasında ilişki kurar", "Elektron dizilimleri $s$ orbitali ile biten elementlerin özelliklerini açıklar", "Metalik ve ametalik özelliklerin periyotlardaki ve gruplardaki seyrini açıklar”, " $p$-Bloku elementlerinde grup özelliklerini listeler" ve "İyonik bağlı bileşiklerin genel fiziksel özelliklerini bağın niteliği üzerinden açıklar" kazanımlarıdır.

Öğretmen görüşlerine göre, programda yer alan etkinlikler konularla tutarlıdır ve programda ayrıntılı olarak yer almaktadır. Programda kullanılması önerilen araç-gereçler konulara uygundur. Ancak program, sınıf ortamında farklı etkinliklerin aynı anda uygulanmasına uygun değildir. Programda kimya öğretimi için önerilen yöntem ve teknikler sınıf düzeyine uygun nitelikte olmadığı gibi Kimyayı sevdirici nitelikte de değildir. Programda önerilen yöntem ve tekniklerden "soru-cevap", "problem çözme” ve "anlatım” en çok kullanılan yöntemler; “deney yapma” ise en az kullanılan yöntemdir. Öğretmen görüşlerine göre, programda belirlenen araç gereçlerden "ders kitabı” sınıf içinde en çok kullanılan; “mikroskop”, “jilet” ve "büyüteç" ise en az kullanılan araç-gereçlerdir. 
Öğretmen görüşlerine göre, Ortaöğretim 10.Sınıf Kimya Dersi Öğretim Programında değerlendirme kazanımlar ve içerikle tutarlıdır. Ancak geleneksel ve performansa dayalı değerlendirme araçları programa uygun nitelikte olmadığı gibi değerlendirme de sadece sınıf içi çalışmalara dayanmaktadır. Programda yer alan değerlendirme araçlarından "kısa cevaplı" sorular, "boşluk doldurma" ve "çoktan seçmeli” test en çok kullanılan; "poster", "broşür " ve "gözlem-takip formu" ise en az kullanılan değerlendirme araçlarıdır.

Öğretmenler programla ilgili yeterince bilgilendirilmemektedirler. Öğretmen görüşlerine göre, programda yer alan kazanımlar öğrencilerin gelişim düzeyine ve hazır bulunuşluğuna uygun değildir. Ayrıca ders süresinin yetersiz olması nedeniyle programda yer alan etkinlikler gerçekleştirilememektedir. Programda önerilen yöntem ve teknik ile araçgereçler yetersizdir. Öğretmenler daha çok düz anlatım yöntemini kullanılmaktadırlar. Konuların sıralanışında önkoşul ilişkiler dikkate alınmadığı gibi etkinlikler de öğrencilerin ilgisini çekecek nitelikte değildir. Programda yer alan etkinlikler ve ölçme değerlendirme örnekleri yetersiz olduğu için öğretmenler daha çok kendilerinin geliştirdikleri soruları kullanmaktadırlar.

2013-2014 eğitim öğretim yılından itibaren uygulanacak olan taslak programın genel amaçları, çalışmada değerlendirilen programın genel amaçları ile benzerlik göstermektedir. Çalışmada değerlendirilen programda yer alan 123 içerik kazanımı, taslak programda 39'a indirilmiştir. Genel olarak taslak programın içeriği hafifletilmiş ve haftada iki ders saatinde işlenebilecek düzeye gelmiştir. Bütün bu sonuçlara bağlı olarak; 2009-2010 eğitim öğretim yılından itibaren uygulanan kimya programı, program değerlendirme yaklaşım ve modelleri çerçevesinde, öğretmen, öğrenci, yönetici gibi katılımcıların da görüşleri alınarak değerlendirilmeden yapılan bu değişikliğin ortaöğretim kimya eğitimine getireceği katk1 tartışılır niteliktedir.

\section{Öneriler}

* Programda yer alan genel amaçlar, öğrencilerin gelişim düzeyine uygun şekilde yeniden düzenlenmelidir.

* Programda yer alan kazanımlara öğrencilerin ulaşabilirliğini arttırmak amaciyla kazanımların sayısı azaltılmalı veya ders saatleri arttırılmalıdır.

* Programda, öğrencilerin ilgisini çekecek nitelikte etkinliklere yer verilmelidir.

* Programda yer alan geleneksel ve performansa dayalı değerlendirme araçları, kazanımlara ulaşılabilirliği ölçecek nitelikte yeniden düzenlenmelidir. 
* Kimya öğretmenlerine, yenilenen programlarla ilgili programlar uygulamaya geçirilmeden önce, alanında uzman kişiler tarafından programın temel yapısı, özellikleri, kullanılabilecek öğretim yöntem ve teknikler ile ölçme ve değerlendirme boyutlarına yönelik kapsamlı bir hizmet içi eğitim verilmelidir.

* Programın değerlendirilmesinde, erişi testi ve düzey belirleme testi gibi farklı veri toplama araçları işe koşulmalıdır. Ayrıca öğretim sürecinin değerlendirilmesi yoluyla program hakkında daha sağlıklı bilgi edinebilmek için gözlemden faydalanılmalıdır.

* Çalışmada değerlendirilen kimya programı ile 2013-2014 eğitim öğretim yılından itibaren uygulanacak olan kimya programını, programın öğeleri kapsamında karşılaştırmaya yönelik betimsel ve deneysel araştırmalar yapılmalıdır.

\section{Kaynakça}

Ayas, A., Çepni, S., \& Akdeniz, A. R. (1993). Development of the Turkish secondary science curriculum. Science Education, 77(4), 433-440.

Ayas, A. (1995). Fen bilimlerinde program geliştirme ve uygulama teknikleri üzerine bir çalışma: İki çağdaş yaklaşımın değerlendirilmesi. Hacettepe Üniversitesi Ĕ̆itim Fakültesi Dergisi, 11, 149-155.

Barın, T. B. (2009). Ortaöğretim kurumlarındaki kimya öğretmenlerinin kimya öğretimindeki sorunlarının ögretmen ve ögrenci görüşlerine göre tespiti (Erzurum ili örneği), Yüksek lisans tezi, Atatürk Üniversitesi Fen Bilimleri Enstitüsü, Erzurum.

Creswell, J. W., Plano Clark, V. L., Gutmann, M. L., \& Hanson, W. E. (2003). Advanced mixed methods research designs. In Tashakkori, A. and Teddlie, C. (Ed.), Handbook of mixed methods in social and behavioral research (p. 209-240). CA: Sage.

Er, K. O. (2006). İlköğretim 4. ve 5. sinıf İnilizce ögretim programlarının değerlendirilmesi, Doktora tezi, Ankara Üniversitesi Eğitim Bilimleri Enstitüsü, Ankara.

Ergin, Ö., Akgün, D., Küçüközer, H., \& Yakal, O. (2001). Deney ağırlıklı fen bilgisi öğretimi. IV. Fen Bilimleri Eğitimi Kongresi 2000 Bildiriler Kitabı, 345-348. Ankara: Milli Eğitim Basımevi.

Greenbowe, T., Burke, K. A., \& Windschitl, M. (1998). Developing and using computer animations for chemistry instruction. Journal of Chemical Education, 75(12), 16581661 . 
Hawkes, S. J. (2001). Chemistry is not a laboratory science. Journal of Chemical Education, 81(9), 1257.

Herron, J. D., \& Nurrenbern, S. C. (1999). Improving chemistry learning. Journal of Chemical Education, 76(10), 1353-1361.

Hounshell, P. B., \& Hill, S. R. (1989). The microcomputer and achievement and attitudes in high school biology. Journal of Research in Science Teaching, 26(6), 543-549.

Johnstone, A. H., (1991). Why is science difficult to learn? Things are seldom what they seem, Journal of Computer-Assisted Learning, 7, 701-703.

Karaaslan, E. H. (2007). Van ili ve çevre ilçelerdeki kimya ögretmenlerinin kullandıkları ögretim metotlarının değerlendirilmesi, Yüksek lisans tezi, Yüzüncü Yıl Üniversitesi Fen Bilimleri Enstitüsü, Van.

Kulik, J. A. (1985). Consistencies in findings on computer-based education. Paper presented at the annual meeting of the American Educational Research Association, (ERIC Document Reproduction Service No. ED263880).

Novak, J. D., \& Gowin, D. B. (1984). Learning how to learn. New York: Cambridge University Press.

Özcan, F. (2000). Öğretmen ve öğrenci algllamalarına göre liselerde kimya öğretiminin sorunlarının ve laboratuarlarda karşılaşılan problemlerin saptanması ve öneriler, Yüksek lisans tezi, Hacettepe Üniversitesi Fen Bilimleri Enstitüsü, Ankara.

Özden, M. (2007). Kimya öğretmenlerinin kimya öğretiminde karşılaştıkları sorunların nitel ve nicel yönden değerlendirilmesi: Adıyaman ve Malatya illeri örneği. Pamukkale Üniversitesi Eğitim Fakültesi Dergisi, 22, 40-53.

Peker, M., \& Mirasyedioğlu, Ş. (2003). Lise 2. sınıf öğrencilerinin matematik dersine yönelik tutumları ve başarıları arasındaki ilişki. Pamukkale Üniversitesi Eğitim Fakültesi Dergisi, 14(2), 157-168.

Schmidt, H. J. (1990). Secondary school students' strategies in stoichiometry. International Journal of Science Education, 12(4), 457-471.

Schmidt, H. J. (1994). Stoichiometric problem solving in high school chemistry. International Journal of Science Education, 6(2), 191-200.

Schmidt, M. E., \& Brosnan, P. A. (1996). Mathematics assessment: Practices and reporting methods. School Science and Mathematics, 96 (1), 17-20. 
Ünal, S., Coştu, B., \& Karataş, F. Ö. (2004). Türkiye'de fen bilimleri alanındaki program geliştirme çalışmalarına genel bakış. GÜ. Gazi Eğitim Fakültesi Dergisi, 24(2), 1832002.

URL-1: http://ogm.meb.gov.tr/ (05.05.2010).

URL-2:http://ttkb.meb.gov.tr/www/guncellenen-ogretim-programlari/icerik/151. 